\title{
Controversies in hormone replacement therapy
}

\author{
A. Baziad
}

\begin{abstract}
Abstrak
Akibat kekurangan hormon estrogen timbul masalah kesehatan jangka panjang maupun jangka pendek, sehingga dapat menurunkan kualitas hidup. Banyak cara yang dapat dilakukan untuk meningkatkan kualitas hidup seorang wanita. Karena masalah yang timbul kebanyakan akibat kekurangan hormon estrogen, maka cara yang tepat adalah dengan pemberian hormon estrogen. Pemberian HRT dengan estrogen dapat menghilangkan keluhan klimakterik, mencegah osteoporosis, penyakit jantung koroner, dimensia dan kanker usus besar. Meskipun penggunaan HRT begitu banyak keuntungannya, namun penggunaannya masih saja rendah dan menimbulkan banyak silang pendapat. Timbulnya silang pendapat karena baik dokter maupun pasien masih menganut pandangan-pandangan lama yang sudah banyak tidak berlaku lagi, telah usang, dan sudah tidak tumpang lagi oleh berbagai penelitian. Dewasa ini pengguna HRT bukan lagi berdasarkan pengalaman, atau pengamatan sesaat saja, tetapi lebih berdasarkan "evidence based medicine". (Med J Indones 2001; 10: 182-6)
\end{abstract}

\begin{abstract}
Deficiency of estrogen hormone will result in either long-term or short-term health problems which may reduce the quality of life. There are numerous methods by which the quality of female life can be enhanced. Since the problems occurring are due to the deficiency of estrogen hormone, the appropriate method to tackle the problem is by administration of estrogen hormone. The administration of hormone replacement therapy (HRT) with estrogen may eliminate climacteric complaints, prevent osteoporosis, coronary heart disease, dementia, and colon cancer. Although HRT has a great deal of advantage, its use is still low and may result in controversies. These controversies are due to fact that both doctor and patient still hold on to the old, outmoded views which are not supported by numerous studies. Currently, the use of HRT is not only based on experience, or temporary observation, but more on evidence based medicine. (Med J Indones 2001; 10: 182-6)
\end{abstract}

Keywords : controversies, HRT

All women, without exception, will one day enter menopausal age which indicates the end of reproductive functions, and with it they arrive at aging process. Being elder is considered to be a disadvantage as this is a period when various health problems begin occurring.

The pace of development to improve the living standard of Indonesian people will be accompanied by the increased life expectancy. The worldwide total population in the $21^{\text {st }}$ century reaches 6.2 billions and by the year 2025 this figure is estimated to be in a range of $8.3-8.5$ billions, and these figures will constantly increase. The group of advanced age

Department of Obstetrics and Gynecology, Faculty of Medicine University of Indonesia / Dr Cipto Mangunkusumo General Hospital, Jakarta, Indonesia people is expected to grow more rapidly than the other age groups. The rapid grow of the advanced age population will be particularly encountered in Asia.

It is estimated that by the year 2025, the number of Indonesian women at menopausal age will reach 35 , 000,000 . In 2000 the number of all European women at menopausal age was $17.5 \%$, while by the year 2010 this figure is expected to reach $20 \%$.

The consequence of estrogen deficiency is the onset of health problems, either short-term or long-term, such that it has become a health, and even socioeconomic, issue of primary importance. The longterm sequel may assume the forms of bone fractures due to osteoporosis, cardiovascular diseases, dementia, and colon cancer all of which may cause a formidable financial burden to the patients and the public. The community should possess ability for 
lowering morbidity of advanced age women to enable them to reach a better quality of life.

There are many methods to be pursued in enhancing the quality of life of advanced age women. Since the problem occurring is closely associated with estrogen deficiency, the most appropriate method to be adopted is the administration of estrogen hormone. The estrogen administration has proved to eliminate various climacteric complaints and prevent women from the incidence of bone fractures, coronary heart disease, dementia, and colon cancer. However, the use of HRT remains a controversy and the doubts of the effectiveness of this therapy in either developed or developing countries still prevail. Doctor and patient may assume that menopause is a physiological process, and complaints of this process are a common thing. Although it is considered as a physiologic process, the complaints arising from this process are treated symptomatically. Generally, patients consume pain-killers, rheumatic medications, or sedatives for years unaware of the complications that may arise.

The doubts and the low use of HRT are more associated with old and outmoded views which are not supported by various current studies. Currently, the use of HRT is not only based on experience, or temporary observation, but more on evidence based medicine, i.e. utilization of latest evidence from studies in patient's management.

This paper attempts to address various aspects which remain a controversy in the use of HRT, to the extent that the negative views on HRT may be eliminated in order to enhance the quality of life of menopausal/ post-menopausal women in Indonesia.

\section{SEVERAL CONTROVERSIES IN HORMONE REPLACEMENT THERAPY}

\section{Too many contraindications}

The are many who assume that HRT has too many contraindications such that there is a fear to administer this therapy to patients. This assumption is due to the fact that the hormonal specimen available in HRT is identical to that available in contraceptive pills. The truth is hormonal specimen available in HRT is of natural hormone type, while hormonal specimen found in contraceptive pills is of synthetic type. The contraindications known so far are abundant, such as myocardial infarct, coronary heart disease, hyper- tension, cerebrovascular abnormalities, varices, diabetes mellitus (DM), hyperthyroid, liver dysfunction, prolactinoma, and many others. All these are contraindications to contraceptive pills, but not to HRT. ${ }^{1,2}$ Nowadays, almost all conditions which are contraindications to contraceptive pills are not contraindications to HRT, they have even become indications to HRT. A great many of the so-called or well-known contraindications are more appropriate to be termed "traditional contraindications".

Currently, the use of contraceptive pills for HRT is being considered for menopausal/post-menopausal women. However, controversies among the experts still prevail since clinical data available are relatively insufficient.

Today only the type of natural estrogen-progesterone is recommended for HRT. The type of natural estrogen is conjugated estrogens, such as equine estrogen and estradiol valerate, 17 beta estradiol, estropipete.

The use of equine estrogen is, however, still controversial although estrogen of this type is most frequently used in the US and Canada and in several Asian countries. Equine estrogen originates from urine of pregnant female horse and contains 9 types of estrogens, consisting of dozens of metabolite products in human blood. This has resulted in controversy as to whether or not a female body should be burdened with so many types of estrogen, ${ }^{3}$ while only one type of estrogen is sufficient to produce the effects of 9 types of estrogen. Although conjugated estrogen (equine) is administered, the side effects occurring are not significantly different from the administration of non-conjugated estrogen.

The type of natural progesterone frequently used today for HRT is medroxy progesterone acetate (MPA), and siproterone acetate (SPA), didrogesterone, and chlormadinone acetate. Although synthetic progesterone, such as noretisterone, is far more effective in preventing endometrial hyperplasia than natural progesterone, its use is not preferable in HRT since in the long-term use it may lower HDL serum level. ${ }^{4}$ The lowered HDL serum level constitutes a risk for coronary heart disease. The combined administration of $2 \mathrm{mg}$ estradiol valerate +0.25 levonogestrel may lower HDL up to $30 \%$, and VLDLC up to $50 \% .^{5}$

Siproterone acetate (SPA) is known for its antiandrogenic effects such that it may raise question as to whether its use will reduce libido in menopausal 
women. SPA will only have its anti-androgenic effect if administered at higher doses, such as $30 \mathrm{mg} /$ daily, while in HRT the dose of SPA is $1 \mathrm{mg}{ }^{6}$

\section{Breast cancer}

One of the causal factors of the low use of HRT is the assumption that HRT may cause breast cancer. In both the HRT users and the non-HRT users, the incidence rate of breast cancer was not different. In industrialized countries, the most leading cause of mortality in women over 50 years was not breast cancer, but coronary heart disease. ${ }^{7}$ One of two women died from heart disease, or stroke, and only one of 25 women died from cancer. In the US, the mortality due to coronary heart disease was 10 fold as high as mortality due to breast cancer.

More than 50 studies have been conducted to observe the relationship between HRT and breast cancer, and they proved that no relationship existed between the incidence of breast cancer and HRT. ${ }^{8,9,10,11,12,13}$ Several studies even discovered the lowered incidence rate of breast cancer in the long-term HRT users. $^{14,15,16,17}$ This may be attributed to the fact that long-term HRT users were active in undergoing early detection with mammography.

Currently, the administration of HRT in women suffering from breast cancer is being attempted. Women with clearly-defined breast cancers, not yet metastasizing, showed that the size of their tumor masses diminished with the HRT administration, and metastasis into lymphatic gland was rarely encountered. ${ }^{18,19}$ It may be concluded that HRT does not have any impact on the receptor status in the breast.

The old assumption that progesterone should be added to prevent breast cancer has now been rejected. In women who do not have uterus anymore, it is sufficient to receive only estrogen. No evidence has been shown that progesterone may protect women from breast cancer.

Up to the present, there are many who still presume that if there is a HRT user in the family of patient who suffers breast cancer, she will likely to develop breast cancer either. This presumption is not based on evidence, and the history of breast cancer in family is not a contradiction any longer to HRT administration. ${ }^{20}$

\section{Weight gain}

Quite often women complain about weight gain during the use of HRT, and generally they blame HRT as its causal factor. Various studies have shown that there is no correlation between the use of HRT and body weight gain. By contrast, the accumulation of fat in the abdomen and in lower extremities was more frequently discovered in women who experienced estrogen deficiency. For instance, suppression of estrogen synthesis by $\mathrm{Gn}-\mathrm{RH}$ analog results in the body weight gain of $0.8 \mathrm{~kg}$, and the gain of body fatty mass of $2 \mathrm{~kg}$, while the volume of body fluid reduces by $0.5 \mathrm{~kg}$.

The accumulation of fat is found in men with low level of testosterone. The accumulation of fat in the abdomen constitutes a greater risk for coronary heart disease than the accumulation of fat in the extremities. In order to eliminate the accumulation of fat, estrogen is administered for women and testosterone for men.

At the beginning of HRT administration, a gain weight of $1-2 \mathrm{~kg}$ will occur. Due to estrogen deficiency the loss of body fluid will occur in the tissues, and HRT administration will produce rehydration. This is a physiologic process and is so expected such that the skin is prevented from wrinkling. However, if weight gain occurs during the use of HRT this may be attributed to intake of high-calorie food. Generally, menopausal women are reluctant to do exercise and many of them experience depression. To overcome this depression, they try to keep themselves preoccupied by eating between meals.

\section{Bleeding during the use of HRT}

One of the causal factors of the low use of HRT in the developing countries is the occurrence of bleeding during the use of HRT. The occurrence of this bleeding is considerably affected by HRT administration. In patients at perimenopausal age, or those who still experience, yet irregular, menstruation, or those who have no menstruation anymore, and yet wish to experience regular menstruation, it is advisable for them to receive HRT continuously. Continuous administration may result in spotting during the first six months of HRT administration. Copious bleeding is generally caused by high-dose of estrogen, while spotting is generally due to high-dose of progesterone. 


\section{Colon cancer}

Another issue that is still being debated is the assumption that HRT may reduce the risk of colon cancer in menopausal women. Colon cancer is more frequently found in women, and its incidence increases with the increase of age. More than 20 epidemiological studies showed that in women using HRT the incidence rate of colon cancer is significantly lower than those who do not use it. ${ }^{22}$ These studies show the presence of protective effects of HRT. ${ }^{23,24,}$ ${ }^{25,26}$ A prospective-cohort study in post-menopausal women receiving HRT discovered the protective properties of HRT against colon cancer. ${ }^{22}$ However, the exact mechanism through which estrogen may reduce the incidence of colon cancer remains unknown. It is suspected that this mechanism is associated with the effect of estrogen on the gall metabolism, or the effect of the suppressing properties of estrogen on the activities of tumor cell receptors. ${ }^{22}$

\section{Duration of HRT use and compliance}

The question frequently raised is how long a patient should use HRT. This question still provokes controversies. However, most experts agreed that in order to prevent bone fracture, cardiovascular disease, dementia, colon cancer, etc., leading eventually to the enhancement of quality of life, HRT should be administered for the rest of the patient's life. ${ }^{27}$ If HRT is terminated abruptly after several years of use, the short-term and long-term complaints will reemerge such as before using HRT. For patients who do not have any complains at all, HRT should be administered continuously for preventing long-term health problems.

In order that patients are willing to continue using HRT, it is necessary to provide them with explanations on the benefits of HRT and the possible side effects during the use of HRT, such as bleeding, weight gain, and breast pain. Each doctor or other medical personnel should allocate sufficient amount of time for his/her patient, and be able to explain the relationship between HRT and the incidence of breast cancer. Mammography should be performed once from one to two years, for either those who use HRT or those who do not. For patients who insist on not using HRT for fearing of breast cancer, it is advisable for them to be administered other types of HRT such as Selective Estrogen Receptor Modulators (SERM). Raloxifen is one of SERM types currently used for preventing osteoporosis and cardiovascular disease. Nevertheless this method is not very effective in eliminating climacteric complaints, and may even result in vasomotoric complaints.

\section{CONCLUSIONS}

The use of hormone replacement therapy (HRT) in both the developed countries and the developing countries is still low, although it is recognized that HRT provides a great deal of benefit for menopausal/ post-menopausal women. The low use of HRT may be attributed more to the knowledge of both the doctor and the patient which is still inadequate. In addition, HRT still provokes controversies among the experts, particularly among them who do not have adequate understanding on reproductive endocrinology. On the contrary, all data on the risks and benefits of HRT are gained from evidence-based medicine, and this should expel any doubts or speculations in the use of HRT. Many doctors recommended the use of phytoestrogen, changes of lifestyle, cosmetic hormones, and alternative therapy for their patients, although these methods of treatment still lack any consensus and are hampered by limited availability of literature.

\section{REFERENCES}

1. Birkhauser MH. Contraindications today, indication tomorrow. In: Menopause, European concensus development conference, Ed. Birkhauser MH, Rozenbaum H. Etitions ESKA. Montreux Switzerland, 1996: 283-9.

2. Kenemans P, Barentsen R, van de Weijer P. Conditions in which HRT in not contraindicated, HRT special conditions. Medicom, 1995:111-4.

3. Lippert TH. Pharmacodynamics and toxicology of different estrogens. Hormone Replacement in Postmenopausal Women: Are All Estrogens Equal ? Programme Schering Workshop. Bali, 24.02.01.

4. Tikkanan MJ, Nikkila EA, Kuusi T, Sipinen S. High density lipoprotein-2 and hepatic lipase:rec iprocal changes produced by estrogen and norgestrel. J Clin Endocr 1982;54:113-7.

5. Tikkanen MJ, Nikkila EA, Kuusi T, Spinen S. Effects of estradiol and levonorgestrel on lipoprotein lipids and postheparin plasma lipase activities in normolipoproteinemic women.Acta Endocr. 1982; 99:630-65.

6. Janne O, Bardin CW. Steroid receptors and hormone action: physiological and synthetic androgens and progestins can mediate inappropriate biological effects. Pharmacol Rev 1984:36;35S-42S.

7. Baziad A, Pache T. Cardiovascular disease and hormone replacement therapy. First consensus Meeting on Menopause in the East Asian Region. Ed. Ratnam SS, Campana A. Medical Forum International. Geneva, 1997: 105-18.

8. Dupont WD, Page DL. Menopausal estrogen replacement therapy and breast cancer . Arch Intern Med 1991;151:6772. 
9. Kaufman DW, Palmer JR, de Mouzon J. Estrogen replacement therapy and the risk of breast cancer: results from the case-control surveillance astudy. Am J Epidemiol 1991;134:1375-85.

10. Palmer JR, Rosenberg L, Clarke EA, Miller DR, Shapiro $S$. Breast cancer risk after estrogen replacement therapy: results from the Toronto Breast Cancer Study. Am J Epidemiol 1991; 134;386-95.

11. Colditz GA, Hankinson SE, Hunter DJ. The use of estrogens and progestins and the risk of bresat cancer in postmenopausal women. N Engl J Med 1995;332:1589. 93.

12. Stanford Jl, Weiss NS, Voigt LF, Daling JR, Habel LA, Rossing MA. Combined estrogen and progestin hormone replacement therapy in relation to risk of breast cancer in middle -aged women. JAMA 1995;274:137-42.

13. Vassilopoulou-Sellin R. Estrogen replacement therapy in women at increased risk for breast cancer. Breast Cancer Res Treat 1993;28:167-77.

14. Bergkvist L, Adami HO, Bergstrom R, Krusemo UB Prognosis after breast cancer diagnosis in women exposed to estrogen and estrogen-progetogen replacement therapy. Am J Epidemiol 1989;130:221-8.

15. Hunt K, Vessey M, McPherson K. Mortality in a a cohort of long -term users of HRT: an updated analysis. $\mathrm{Br} \mathrm{J}$ Obstet Gyneacol . 1990;97: 1080-86.

16. Henderson BE, Paganini-Hill A, Ross RK. Decreased mortality in users of estrogen replacement therapy. Arch Intern Med.1991:151:75-8.

17. Willis DB, Calle EE, Miracle-McMahill HL, Heath CW Jr. Estrogen replacement therapy and risk of fatal breast cancer in a prospective cohort of postmenopausal women in the United States. Cancer Causes Control.1996;7:449. 57.

18. Collaborative Group on Hormonal Factors in Breast Cancer: Breast cancer and hormone replacement therapy:
Collaborative reanalysis of data from 51 epidemiological studies of 52705 women with breast cancer and 108411 women without breast cancer. Lancet. 1997;350:1047-59.

19. Harding C, Knox WF, Faracher EB, Baildam A, Bundred NJ. Hormone replacement therapy and tumour grade in breast cancer: prospective study in screening unit. $\mathrm{Br}$ Med J.1996;312:1646-7.

20. Sellers TA, Mink PJ, Cerhan JR. The role of HRT in the risk for breast cancer and total mortality in women with a family history of breast cancer. Ann Intern med. 1997; 127:973-80.

21. Revilla R, Revilla M, Vilta LF, Cortes J, Arribas I, Rico $H$. Changes in body composition in women treated with gonadotropin-releasing hormone agonist. Maturita. 1998; $31: 63$.

22. Calle EE. Hormone replacement therapy and colorectal cancer: interpreting the evidence. Cancer Causes Control. 1997;8:127-9.

23. Furner SE, Davis FG, Nelson RL. A case control study of large bowel cancer and hormone exposure in women. Cancer Res .1989;49:4936-40.

24. Gerdhardsson de Verdier M, London S. Reproductive factors, exogenous female hormones, and colorectal cancer by subsite. Cancer Causes Control 1992;3:355-60.

25. Newcomb PA, Storer BE, Marcus PN. Cancer of the large bowel in relation to the use of HRT. Am J Epidemiol 1992;136:958.

26. Newcomb PA, Storer PA. Postmenopausal hormone use and risk of large - bowel cancer. J Natl Cancer Inst. 1995;87:1061-71.

27. Uwe Holihn K. Hormone Replacement Therapy and the Menopause. Strategic Business Unit. Fertility Control \& Hormone Therapy. Shering AG. 2 nd edition, June 1997. Germany 1997:100 